\title{
Impact of the pandemic on the industrial development (Rostov region as the example)
}

\author{
Gurgen Malkhasyan ${ }^{1}$, and Oksana Savelyeva ${ }^{2 *}$ \\ ${ }^{1}$ Ministry of Industry and Energy of Rostov Region, 344050, Rostov-on-don, 112 Sotsialisticheskaya \\ str., Rostov-on-Don, Russia \\ ${ }^{2}$ Don State Technical University, 1, Gagarin Square, 344003, Rostov-on-Don, Russia
}

\begin{abstract}
The article is devoted to the development of the industrial complex in the conditions of spreading of new coronavirus infection. The following points are considered in the article: the main forms and tools of state support for industrial enterprises in the Rostov region in the context of the pandemic, measures taken by the Government of the Russian Federation and regions to reduce the negative impact of the pandemic on industries and stabilize the work of industrial enterprises.
\end{abstract}

\section{Introduction}

The 2020 pandemic has become a global economic, social and environmental challenge for all countries and businesses. For several months, the usual way of life was ceased.

The ability to adapt to new conditions quickly allowed many industrial enterprises to survive quarantine and build business processes in a new way.

Domestic industrial enterprises introduced preventive measures, trying not to stop working processes, while visits to the production area, business trips and meetings in the office were minimized. Companies that were able to implement digital tools quickly and to work remotely have become more efficient. Before the pandemic, work on the "remote" was a prerogative in the field of IT, SMM, design and a number of other professions. But under the new conditions, only the adoption of flexible and non-standard solutions allowed industrial companies to minimize the negative impact of the pandemic of coronavirus infection on their economy and development.*

It should be noted that over the past five years, the Rostov region has maintained a positive dynamics of industrial production growth.

*Distance work as a trend of time: the results of mass experience - the topic of a scientific article on economics and business, read the text of the research work for free in the CyberLeninka electronic library (cyberleninka.ru).

\footnotetext{
*Ccorresponding author : avlas333@mail.ru
} 


\section{Problem formulation}

In 2020, the socio-economic development of the region was influenced by difficult situation associated with the spread of a new coronavirus infection and worsening world conditions. At the same time, the index of industrial production of the Rostov region, according to Rostovstat, at the end of 2020 year amounted to $101.7 \%$ to the level of 2019 year with the average Russian indicator - 97.1\% (Fig. 1).

The continuation of the final positive dynamics is ensured by the work of leading industrial companies, especially manufacturing economic activities:

- Production of chemicals, electrical equipment and finished metal products increased by more than $30 \%$,

- About 5\% added oil refining, metallurgy, industries for the production of non-metallic mineral products.
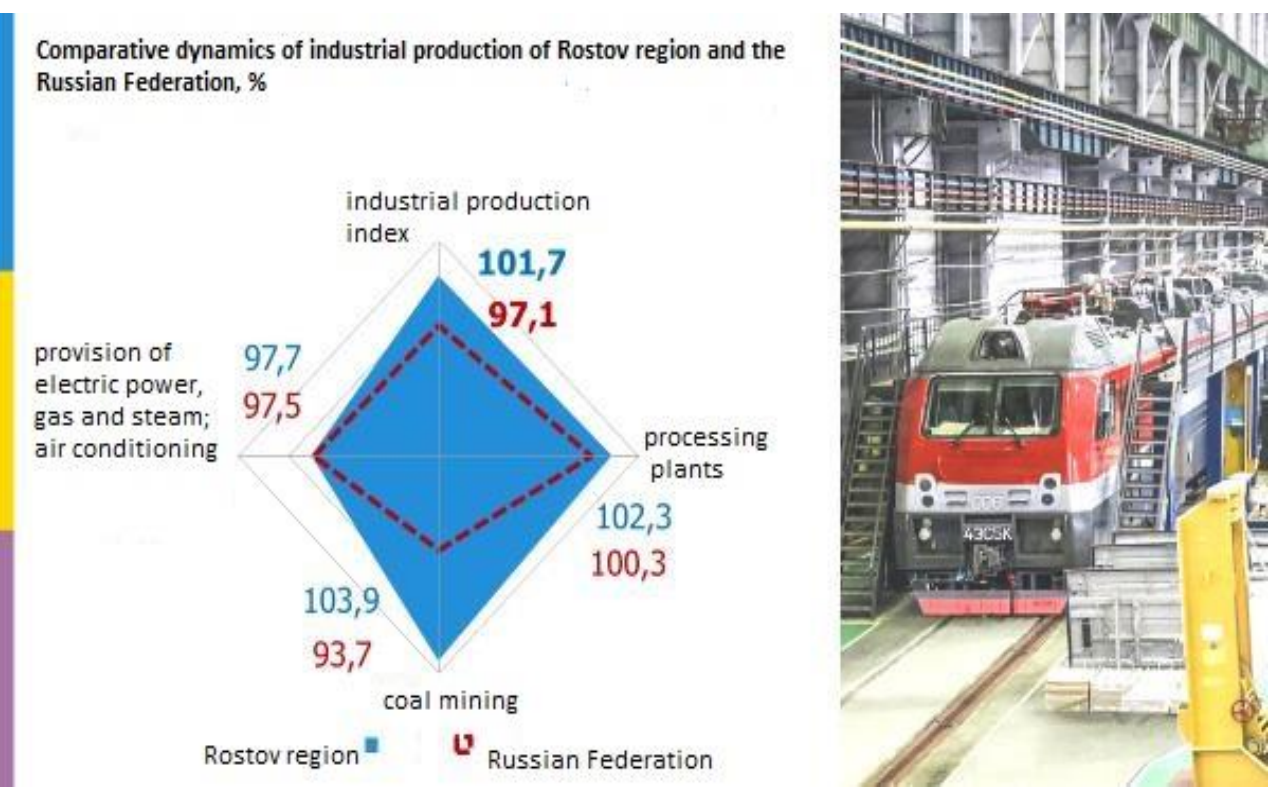

Fig. 1. Comparative dynamics of industrial production of Rostov region and the Russian Federation, $\%$.

In 2020, a positive settled financial result was achieved for 13 of the 21 supervised economic activities (for January-October 2020) and amounted to 24.3 billion rubles. However, this value is $22 \%$ lower than last year.

It should be noted that changes in order portfolios and sales volumes through retail chains did not significantly affect the financial results of the industrial companies. The value of profit on manufacturing activities was slightly reduced (by $8 \%$ compared to 2019).

According to the operational monitoring [1] data of the ministry, the investments mastered by large and medium-sized organizations of industrial and fuel and energy complexes by the end of 2020 were increased by $30 \%$ compared to 2019 and amounted to about 62 billion rubles.

In current conditions, these are quite positive indicators.

In 2020, the region continued to implement all key areas of modern industrial policy, including areas within the framework of the Strategy for socio-economic development of the Rostov region for the period until 2030 and national projects. 
In April 2020, the Government of the Rostov Region adopted a plan of priority events to ensure the sustainable development of the economy and social stability in Rostov Region in the conditions of spreading of coronavirus infection ( $69 \mathrm{rg}$ from 02.04.2020).

\section{Materials and methods}

As part of the implementation of this Plan, several proposals were prepared for measures of state support for companies at both the federal and regional levels [2].

Thanks to the address of the Governor of Rostov region V.Yu. Golubev to the Russian Prime Minister M.V. Mishustin, the list of the most affected industries by spreading of new coronavirus infection (Russian Federation Government decree of 03.04.2020 No. 434) was complemented with a type of activity "Production of products of national art crafts" (Russian Federation Government decree of 12.05.2020 No. 657).

And the types of activities for the production of fabrics, textiles and outerwear are included in the List of sectors of the Russian economy that require support for the resumption of activities (Decree of the Government of the Russian Federation dated 16.05.2020 No. 696).

In order to support leading industrial companies in the region, significant work has been carried out to supplement the List of systemically important companies at the federal level (included: Gloria Jeans Corporation, Atlantis-Pak PCF; for consideration by the Government Commission: Alice Fashion Rus, Donobuv, Lemax).

These measures allowed industrial organizations to receive preferential loans for the resumption of activities (Stellar, Aksinya (Semikarakorskaya Ceramics), Donetsk Factory and others) [3].

At the regional level, the mechanism of the Regional Industrial Development Fund was used.

\section{Results}

In November 2019, the Fund was pre-financed by 300 million rubles in accordance with the Regional Law of 25.07.2019 No. 173-ZS "On Amendments to the Regional Law" On the Regional Budget for 2019 and for the Planning Period 2020 and 2021. "

In 2020, some changes were made to the Fund Standard on providing financial support to industry entities under the Cost Reduction program. These changes provide for a loan at $1 \%$ per annum to manufacturers of personal protective equipment and disinfectants. This allows companies to increase the production of personal protective equipment and disinfectants rather quickly, directing funds to replenish working capital, purchase production equipment and materials in a pandemic.

In 2020, the Fund provided support for 18 projects of industrial enterprises totaling 314.5 million rubles. In 2021, 1 project has already provided a loan for 20.0 million rubles, another 2 applications have been approved.

The projects funded by the regional fund are:

- 3 companies - manufacturers of personal protective equipment in 2020: ProGreen (diesel equipment, Rostov-on-Don), Factory (masks, Taganrog) and SHO Flagman (masks, Donetsk);

- 5 participants of the national project "Labor productivity and employment support": "Lemax," "10 GRZ," "Almaz," "Clover," "Alice Fashion RUS";

- 2 organizations - residents of TOSER Donetsk: Lokomotiv-Service-Rostov (2018) and SHO Flagship (2020). 
Currently with the companies Lemax, BTK, Almaz and PromVyazhmash, the issue of preparing packages of documents for participation in the program of providing joint loans with the FRP for the implementation of investment projects is being worked out.

In developing the issue of expanding funding programmes:

- For defense industry enterprises producing civilian products, at 1\% per annum;

- for companies participating in clusters and industrial parks included in the register of the Ministry of Industry and Trade of Russia, at 3\% per annum.

At the same time, the possibility of creating a "single window" for industrial enterprises is under the consideration. Its main function is to inform about the temporary state support measures and to assist in obtaining it at the federal and regional levels [4].

Thus, an important task in the pandemic is the recapitalization of the Regional Industrial Development Fund for 300 million rubles annually.

Currently, the Government of the region is conducting weekly monitoring of the level of utilization of production capacities of enterprises, including systemically important ones, and compliance with the recommendations of Rospotrebnadzor.

At most enterprises of industrial and fuel and energy complexes [5], the loading level is from 60 to $100 \%$.

The heads of organizations have taken measures to provide employees with all the necessary protective equipment, and special equipment is regularly treated with all publicly available surfaces [5].

Of course, the fulfillment of the requirements of Rospotrebnadzor provides for the need to cover all categories of consumers with SIZs and DIZs in the face of growing demand.

Before the pandemic began [6] the volume of medical mask production in the region amounted to 5-10 thousand products per day only, now the existing production facilities allow producing up to 200 thousand medical masks, that is, 20 (40) times more.

Disinfectant manufacturers increased daily production capacity by more than 4.5 times to 315 tons.

Production of antiseptic products was launched by Novocherkassk Lubricants Plant, O3 Group of Companies, Avant Group of Companies, Stanko-Group Rus, Gint [7].

BTK began mass production of a protective reusable insulating jumpsuit from a new membrane three-layer fabric. More than 34 thousand costumes were produced.

This year the region continued to implement investment projects, including those that are in the Governor's Hundred.

\section{Discussion}

Today the Governor's Hundred has more than 15 investment projects of industrial and fuel and energy complexes worth about 50 billion rubles. In 2020, 4 projects were completed with a total investment of more than 2 billion rubles (Ama-Don LLC, Lemax LLC, KZ Rostselmash LLC, VetroStroyDetail LLC), including:

- Ama-Don completed the expansion of the existing production of musle for sparkling wine producers (investment volume - 300 million rubles);

- Lemax launched the second stage of the plant for the production of steel panel radiators (investment volume - 650 million rubles). Production capacity doubled. Currently, the modernization of the domestic gas equipment plant has begun;

- "Rostselmash Combine Plant began mass production of a new family of high-performance fodder harvesters RSM F (investment volume - 204 million rubles). The company continues the process of introducing components of domestic production. A separate workshop for the production of mechanical transmissions of the Japanese company OKUBO GEAR has been created. 
- "VetroStroyDetail" organized industrial production of modular steel towers for wind power plants with a capacity of $2.5 \mathrm{MW}$.

At the same time, the Governor's Hundred was supplemented by 4 projects of Kamenskvolokno, BONUM, PromTyazhmash, Lemax companies with a total value of about 3 billion rubles.

The issue of inclusion in the Governor's Hundred is being worked out by NZNP, FLASH, Al Pako, NAIS. [8].

The most important support tool was the implementation of special investment contracts

Currently four contracts are being implemented in the region, which will attract about 6.4 billion rubles of investment to the region and will ensure the creation of five hundred (474) new jobs.

Three of the four SPICs concluded are related to the implementation of projects for the creation of key components and units of equipment for wind power plants.

Currently industrial companies are working on the possibility of concluding new contracts.

Thus, Empils is forming a package of documents to submit an application $[8,9,10]$ to the Ministry of Industry and Trade of Russia for the inclusion of a new technology for the production of zinc whitefish in the list of types of technologies recognized by modern technologies.

The technology of plasma atomization of copper nanopowders for the new generation of threaded lubricants of NZSM Company is included in the List as part of the project to organize the production of new generation threaded lubricants [11].

Rostselmash, as part of a special investment contract, plans to implement 2 investment projects to organize the production of small-power transmissions and tractors from 90 to 130 horsepower.

In 2020, with the support of the regional Government the Novocherkassk Industrial Park was included in the register of industrial parks of the Ministry of Industry and Trade of Russia (Order of the Ministry of Industry and Trade of Russia dated 15.06.2020 No. 1886).

The number of residents is about 50 organizations. More than 400 new jobs have been created.

\section{Conclusions}

Inclusion in the register of the Ministry of Industry and Trade of Russia will allow to apply for state support at the federal level (subsidizing part of the costs of paying interest on loans for the implementation of investment projects, and the possibility of subsidizing the costs of creating park infrastructure) $[12,13]$.

In conclusion, over the past 5 years, more than 20 large projects of industrial and fuel and energy complexes have been commissioned in the region, with a total cost of about 300 billion rubles. As a result, about 3 thousand jobs were created and preserved $[14,15]$.

In current conditions, the further stable development of the industrial complex of Rostov region largely depends and is determined by the systematic support and effective implementation of industrial policy at all levels of government. 


\section{References}

1. I. Avlasenko, L. Avlasenko, I. Peshkhoev, Yu. Podkolzin and O. Savelyeva, E3S Web of Conferences 175, $12006 \quad$ (2020), https://doi.org/10.1051/e3sconf/202017512006

2. I. G. Ushachev, A. F. Serkov, V. V. Maslova, V. S. Chekalin, The growth and development of agro-industrial production needs an integrated approach, 4, 4-15 (2016)

3. I. M. Peshkhoev, I. V. Avlasenko, O. V. Panfilova, et al., Advances in Intelligent Systems and Computing, Springer, Cham, 726, 67-71 (2018), DOI: https://doi.org/10.1007/978-3-319-90835-9_8

4. I. G. Ushachev, Main directions of the strategy for sustainable socio-economic development of the agro-industrial complex of Russia, 6, 4-24 (2017)

5. A. K. Subaeva, Scientific and Methodological Electronic Journal "Concept.", 3, 31863190 (2013)

6. T. V. Zhukova, O. V. Panfilova, I. V. Avlasenko, et al., Deformations of the Global Financial System in the Conditions of Globalization, in Proceedings of International Conference Project "The future of the Global Financial System: Downfall of Harmony" ISC 2018: The Future of the Global Financial System: Downfall or Harmony (2018)

7. A. A. Yakushev, Yu. V. Lysenko, International Journal of Economics and Financial Issues, 8(6), 157-166 (2018), DOI: https://doi.org/10.32479/ijefi.7178

8. N. Egorova, Economics and the Mathematical Methods, 56(3), 79-90 (2020), DOI: 10.31857/S042473880010548-1

9. A. I. Chernikova, A. B. Vishnyakova, Science of the XXI Century: Actual Directions of Development, 2(2), 207-212 (2016)

10. T. A. Vishnyakova, Scientific and Methodological Electronic Journal «Concept», 8 (2018)

11. N. V. Babintseva, Journal of Economics and Entrepreneurship, 11(52-4), 609-612 (2014)

12. V. V. Podshivalova, Economics and Management: Analysis of Development Trends and Prospects, 25 (2016)

13. V. V. Lysenko, Theoretical Economy, 3(7), 1-80 (2018)

14. N. E. Egorova, A. F. Akhmetshin, International Journal of Advanced Biotechnology and Research (IJBR), 8(1), 1-16 (2017), ISSN 0976-2612, Online ISSN 2278-599X

15. A. N. Baranov, Journal of Economics and Society, 6(37), 228-231 (2017) 